\title{
Application of a grant in thermal reconditioning houses in the Metropolitan Region of Chile
}

\section{Aplicación de un subsidio de reacondicionamiento térmico de viviendas en la Región Metropolitana de Chile}

Danny Pavez Gallegos (Main Author)

Escuela de Construcción Civil, Facultad de Ingeniería, Pontificia Universidad Católica de Chile

Ave. Vicuña Mackenna 4860, Macul, Santiago (Chile)

dlpavez@uc.cl

Leonardo Meza Marín (Corresponding Author)

Escuela de Construcción Civil, Facultad de Ingeniería, Pontificia Universidad Católica de Chile Ave. Vicuña Mackenna 4860, Macul, Santiago (Chile)

Imezam@uc.cl

Manuscript Code: 997

Date of Acceptance/Reception: 30.08.2018/31.10.2017

DOI: 10.7764/RDLC.17.3.401

\begin{abstract}
Currently in Chile several programs are used in order to promote sustainable construction. On this scenario was created S.D. $\mathrm{N}^{\circ}$. 255 of the House and Urban Development Minister of Chile which, among other objectives, seeks to thermally refurbish houses to provide greater comfort to the inhabitants of this. In practice, this thermal reconditioning has not been implemented in the Metropolitan Region due to in none of its versions funds have been allocated to it. This paper quantifies how much the social benefit would increase if the subsidy was applied in RM. For this, various representative dwellings of housing stock were modeled and was done an economic analysis that led to the conclusion that it is beneficial, at least from a social standpoint, its application.
\end{abstract}

Key words: Saving, simulation, houses of social interest, bioclimatic architecture, energy efficiency.

\section{Resumen}

Actualmente en Chile se utilizan varios programas para promover la construcción sostenible. Dentro de este escenario fue creado el S.D. N 255 del Ministerio de Vivienda y Urbanismo de Chile que, entre otros objetivos, busca renovar térmicamente las casas para brindar mayor comodidad a los habitantes de este. En la práctica, este reacondicionamiento térmico no se ha implementado en la Región Metropolitana ya que en ninguna de sus versiones se le han asignado fondos. Este documento cuantifica el beneficio social que significaría si el subsidio se aplicara en RM. Para esto, varias viviendas representativas del parque residencial fueron modeladas y se hizo un análisis económico que llevó a la conclusión de que es beneficioso, al menos desde un punto de vista social, su aplicación.

Palabras clave: Ahorro, Simulación, Viviendas de interés social, Arquitectura bioclimática, Eficiencia Energética.

Introduction

\section{Energy area in Chile}

The $60 \%$ of consumed energy in the country is imported (División de Prospectiva y Política Energética del Ministerio de Energía, 2012).

Approximately one third of the country's energy is used by residential buildings (Ministerio de Energía, 2014) and from that a study by the Corporación de Desarrollo Tecnológico (Corporación de Desarrollo Tecnológico [CDT], 2010) points out that heaters are the main consumers (56\%) followed by Domestic Hot Water (DHW) and kitchen (Figure 1). 


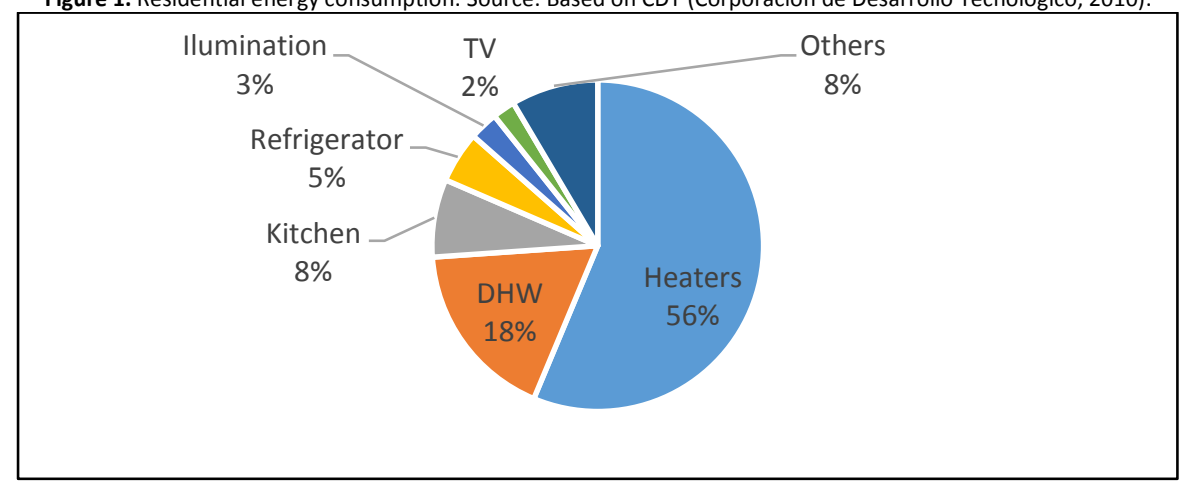

\section{Residential Area in Chile}

According to CDT (Corporación de Desarrollo Tecnológico, 2010) there were 5,261,252 built domiciles until the research date. $85.6 \%$ of houses were made before the first thermal regulation was published (before 2000), meaning that, by the time they were built, it was not mandatory to satisfy any regulation regarding the surround thermal behavior. However, $12.8 \%$ of houses can be considered to have thermal insulation in the ceiling for being built during 2001 and 2007 , and the rest of them (less than $2 \%$ ) would meet with the wall, ceiling and floor thermal regulation which were erected after 2008.

In regard to materiality, according to the same study, it is presented predominance of masonry, wood or partition walls and reinforced concrete as main construction materials (48.8\%; $26.5 \%$ and $12 \%$ respectively). On the other hand, $38.7 \%$ of houses are row house, $37.8 \%$ are insulated, $14.1 \%$ are flats and $9.4 \%$ are row housings in the country.

The domicile's location, regarding thermal zoning (Thermal zoning is a concept that is coined from 7 areas defined on OGUC art. 4.1.10 diving country, according to another concept called degree-day that is the difference between $15^{\circ} \mathrm{C}$ and the temperature of a day whenever this is less than $15^{\circ} \mathrm{C}$ ), CDT (Corporación de Desarrollo Tecnológico, 2010) shows that the Z3 possesses the $43.50 \%$, being followed by Z4 with $18.40 \%$ and Z2 with $14.50 \%$.

\section{The energy Area in Metropolitan Region (in forward RM)}

According to CDT's study (Corporación de Desarrollo Tecnológico, 2010), the thermal zone 3, which is mostly the RM and VI region housing area (Lat. -33,083333 until Lat. -34,853740), was added to the thermal zones 4 and 5 due to similar house typology.

The former group's energy intake distribution at residential level shows that the top consumptions are heating with $56.7 \%$, ACS with $17.5 \%$ and kitchen with $7.3 \%$. Focusing on that $56.7 \%$ of heating, the intake is generated mainly through the usage of GLP, followed by paraffin and then the electric heater.

\section{Residential Area in RM}

From Census information (Instituto Nacional de Estadísticas, 2012) it is concluded that RM agglomerates the 36.6\% of houses in the country $(2,096,962$ until 2012).

According to CDT (Corporación de Desarrollo Tecnológico, 2010) from the previous amount, it would be predominance in one-storey row house, two-storey row house and two-storey insulated houses, in which the $27.3,16.3$ and $6.0 \%$, respectively; were built with reinforced masonry. Also, the flat typology of reinforced concrete represents the $14.6 \%$.

The foremost goal of this research is to show an important advantage that would have the hypothetical implementation of PPPF in the housing area of RM, in particular the "2th title" to measure and quantify these advantages and to express them as economic benefits.

Specifically, it was intended to perform based in Preparation and Project Evaluation General Methodology (Ministerio de Desarrollo Social, 2013). 
$\mathrm{RM}$ is the region where most of domiciles in Chile are located. If the relation between after the thermal regulation entrance built houses stayed the same ( $86 \%$ of houses were constructed before the thermal regulation entry), near to $1,803,400$ houses would need thermal reconditioning.

The former allows infer that the families that inhabit those houses must be heated at one point of the year and, as CDT (Corporación de Desarrollo Tecnológico, 2010) trend displays; this heating is produced generally by GLP heaters.

Permanently, the House and Urban Development Minister has not allocated funds to "2th title" for the PPPF (Ministerio de Vivienda y Urbanismo [MINVU], 2006) of RM.

This research pretends to show, the social benefit is greater than the expense in which the families incur to heat their domiciles compared to the representative period of time if the PPPF was applied in the segment of houses located in RM.

\section{Research Scope and Limitations}

This research has as scope the Residential Area of built living places in RM.

The assumptions that are taken into consideration are:

- The percentage of houses that require heating is $86 \%$ according to the previously stated. Translating this to a quantity is $1,803,400$ houses.

- There is predominance of reinforced masonry materiality and one-storey row house, two-storey row house and twostorey insulated architecture with 27.3, 16.3 and 6.0\%, respectively. As described in subtitle Residential Area in RM of the Introduction.

- $14.6 \%$ of living places are flats with reinforced concrete materiality. As described in subtitle Residential Area in RM of the Introduction.

Methodology

For the fulfilment of this research, 43 cadaster houses in 2014 were taken as sample.

From that sample, four houses were selected as study objects, procuring these living places satisfy the necessary requirements to apply for the PPPF.

Some of the requirements are:

- Social Houses defined in DL n²,552, of 1979.

- Housing groups that are referred in articles 40 and transient of the $n^{\circ} 19,537$ law.

- Living places which appraisal is not higher than UF 650 (The UF is a unit account which is adjustable in regards with the inflation. For this research the UF was established in UF $1=$ CLP 27,200) according to the PPPF calculation methodology.

This means that the houses are required to not overpass UF 650 of fiscal appraisal and the inhabiting families do not possess more than 13,484 points in the social protection file.

Then, according to what was formerly stated by the CDT (Corporación de Desarrollo Tecnológico, 2010) study, most representative house typologies that were selected are:

- One-storey row house.

- Two-storey row house.

- Two-storey insulated.

- Flat / Apartment.

The predominant materiality is reinforced masonry for the first three and reinforced concrete for the fourth. 
As was said in point 1.4 and 4, is supposed that the four cases represent near to $64.6 \%$ of Residential Area in RM.

In Table 1 is presented a summary chart of the four selected houses.

Table 1. Houses of San Bernardo, Puente Alto, Maipú and San Miguel district. Source: Self-authorship

\begin{tabular}{|c|c|c|c|c|}
\hline District & $\begin{array}{c}\text { House } 1 \\
\text { San Bernardo }\end{array}$ & $\begin{array}{c}\text { House } 2 \\
\text { Puente Alto }\end{array}$ & $\begin{array}{l}\text { House } 3 \\
\text { Maipú }\end{array}$ & $\begin{array}{c}\text { House } 4 \\
\text { San Miguel }\end{array}$ \\
\hline House type & $\begin{array}{c}\text { One-storey row } \\
\text { house }\end{array}$ & $\begin{array}{c}\text { Two-storey row } \\
\text { house }\end{array}$ & Two-storey insulated & Flat-like house \\
\hline $\begin{array}{l}\text { Predominant } \\
\text { materiality }\end{array}$ & $\begin{array}{l}\text { Reinforced } \\
\text { masonry }\end{array}$ & $\begin{array}{c}\text { Reinforced } \\
\text { masonry }\end{array}$ & Reinforced masonry & Reinforced concrete \\
\hline $\begin{array}{l}\text { Municipal } \\
\text { reception year }\end{array}$ & 1990 & 2012 & 1993 & 1999 \\
\hline Surface $\left(m^{2}\right)$ & 65 & 42 & 108 & 69 \\
\hline
\end{tabular}

\section{Living place 1}

The first is a one-storey row house of predominant reinforced masonry materiality located in San Bernardo district. All day occupation is presented with a peak of activity on working days. During weekends, Sunday is highlighted for the family stays inside a big part of the day. It is important to mention that the house has various non-regularized extensions and modifications. In specific: a bathroom (bathroom 2) and a room (room 4) were added. Besides, a division was erected between room 4 and room 1, among other alterations. Figure 2 shows an inside view of Living place 1 in Design Builder software.

Figure 2. Living place 1 in Design Builder. Source: Self-authorship.

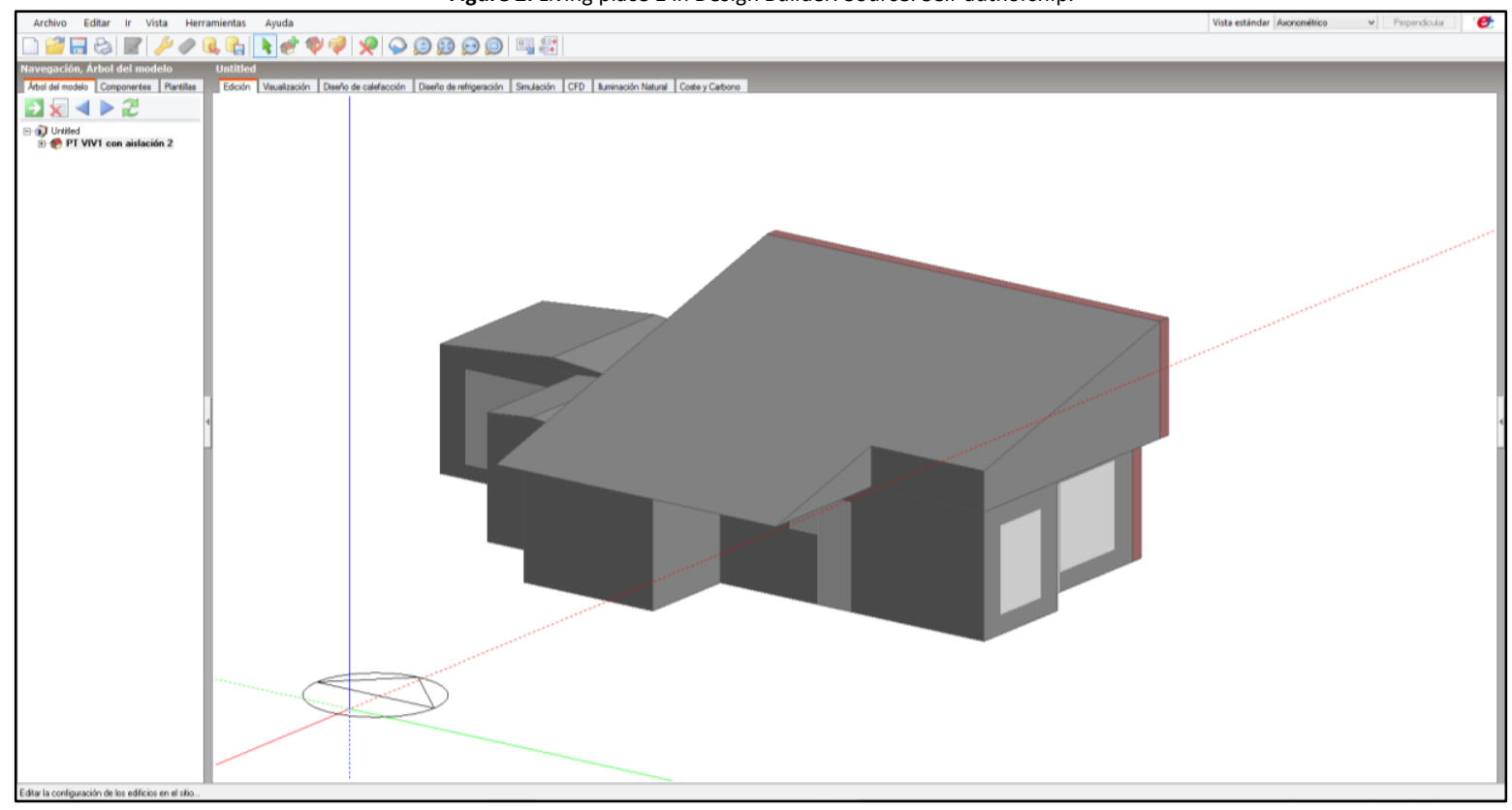

\section{Living Place 2}

It is a two-storey row house house with masonry materiality in the first floor and wooden partitions in the second floor. It is located in Puente Alto district. All day occupation is presented with a peak of activity in the sleeping hours during working days. In the weekends, Sunday is highlighted for the family stays inside a big part of the day. This house has not been architectonically intervened.

\section{Living Place 3}

It is a two-stored insulated with masonry materiality in both storeys with lightweight structure partitions to divide some spaces. It is located in Maipú district. All day occupation is presented with a peak of activity in the sleeping hours during 
working days. This house has been highly architectonically modified throughout the years. In specific, rooms 1 and 4 and the second-storey bathroom were constructed. Both storeys plans are displayed with red demarcation showing the original state of the house. Figure 3 shows an inside view of Living place 3 in Design Builder software.

Figure 3. Living place 3 in Design Builder. Source: Self-authorship.

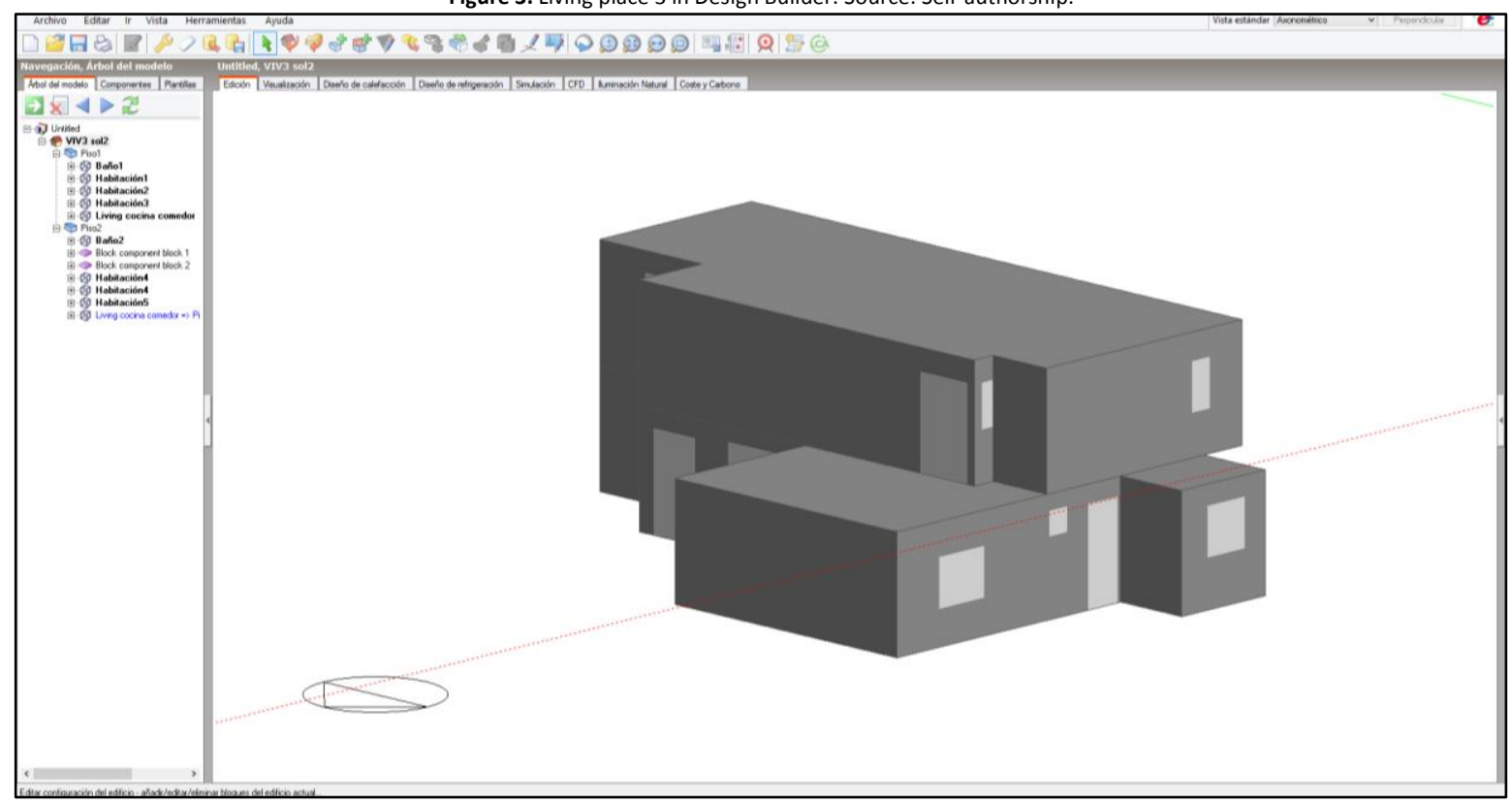

\section{Living Place 4}

It is a flat-like house with predominant reinforced concrete materiality. It is located in a 13 storeys building in the second stored in San Miguel district. This house is normally occupied by two inhabitants and the peak of activity is produced in the sleeping hours. Not exist architectonical interventions. Figure 4 shows an outside view of Living place 4 in Design Builder software.

Figure 4. Living place 3 in Design Builder. Source: Self-authorship.

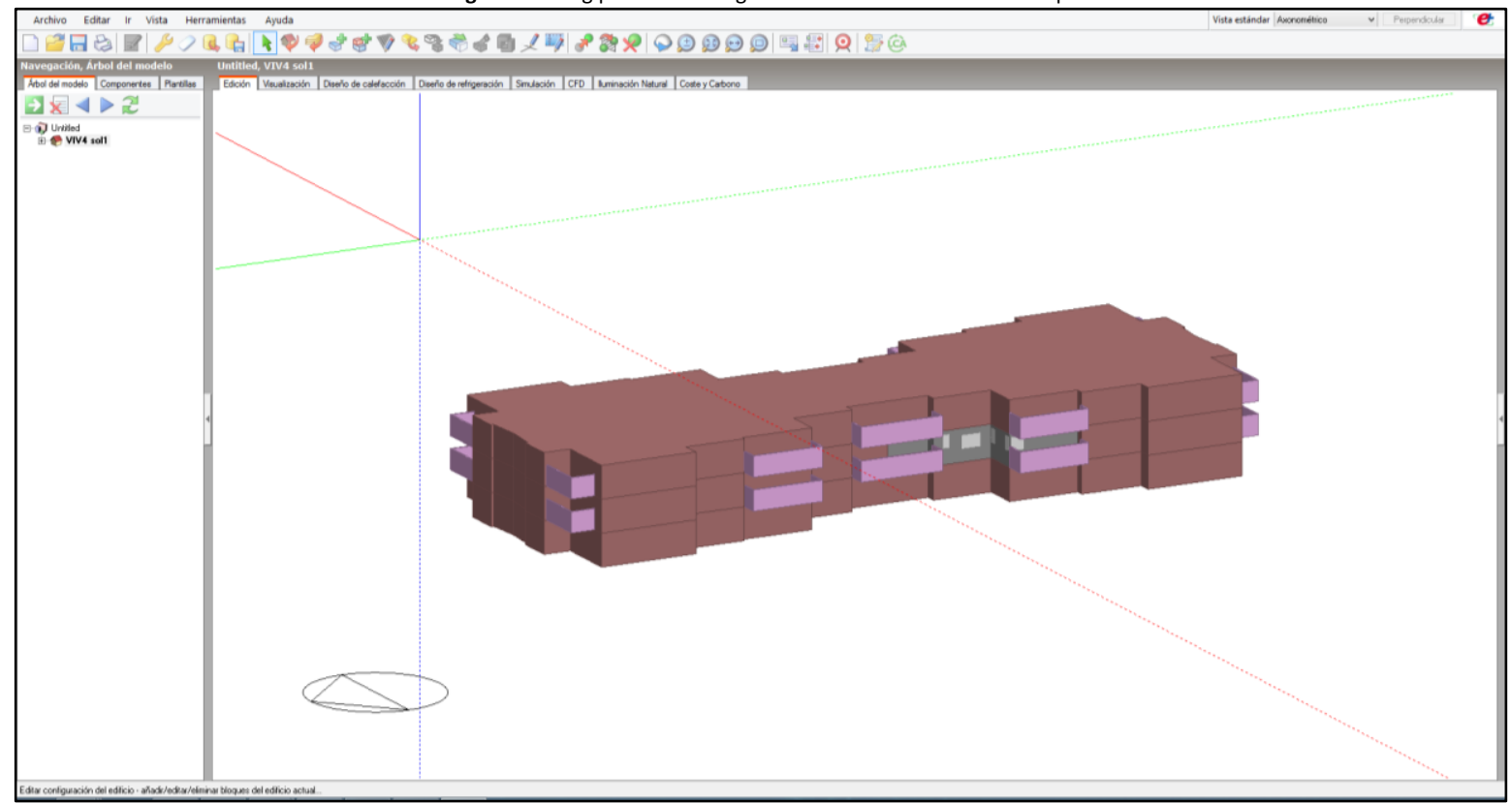

\section{Simulation Process}

There are diverse types of computers programs currently that would allow estimate the thermal charges for the previously analyzed cases. Some of them can be named such as Open Studio with E+( E+, or Energy Plus, is an energy simulation software for an entire building, vastly used by engineers, architects and researchers), Green Building Studio, 
EDSL Tas, Ecotect, Design Builder with E+, TRNSYS, HEED among others (Lobos, Wandersleben, \& Vastillo, 2013). Each one of these exhibits different features that make them be used by various professionals.

For this research, the utilized computer program was Design Builder. García-Alvarado, González, Bustamante, Bobadilla, \& Muñoz (2014), for instance, classifies one of the computers programs with superior capacities naming it as one of the most complete due to its higher detail level in modeling, equipment description, schedules, weather files and relation with others types of computers programs.

It is essential to mention that in order to have valid and comparable results for the simulation process, the details of modelling equipment description, stay schedules in various enclosures, heater occupation schedules, materiality, etc. were the same for any case. One year was simulated in any case.

On the other hand, the weather files were acquired from the computer program Meteonorm, which is largely used in Chile for these purposes (González Cáceres \& Díaz Cisternas, 2013). And was got the weather file of the exact location in any case

\section{Thermal Conditioning Systems Selection}

The modelled thermal conditioning systems were selected from the MINVU's list "Soluciones Constructivas para el Acondicionamiento Térmico". This list has an archive of insulating that can be used for MINVUs projects and it is presented, among other pieces of information, the thermal resistance of the constructive solution. Scilicet, it is the Thermal Resistance of the solution ranging by the masonry wall or concrete and the insulating.

This was made by choosing the alternatives that were suitable for the masonry walls (for the first three cases) and the concrete (for the fourth case). The detailed list is:

In order to execute the previous table, a set of Unitary Price Analysis (UPA) was developed to the constructive solutions; meaning that it was calculated how much would cost to coat $1 \mathrm{~m}^{2}$ of the living places with each one of the insulating. To do that, the different manuals that are offered by the providers were consulted and professionals and companies were asked.

It is important to highlight that said UPA is an estimate value, therefore are not necessarily representative of any context. There are a high number of factors that can influence the final value; for example: economy of scale, market conditions, utilities and losses percentages, presence of dealers etc. Because of this, the values are only useful only for this research.

\section{Thermal conditioning results}

The obtained results from the living places' simulations show the following annual heating demands:

\begin{tabular}{lcccc}
\multicolumn{6}{c}{ Table 3. Annual heating demands. Source: Self-authorship. } \\
\hline House & 1 & 2 & 3 & 4 \\
\hline Heating demand $\left(\mathrm{kWh} / \mathrm{m}^{2}\right)$ & 122.35 & 98.61 & 154.18 & 46.04 \\
\hline
\end{tabular}




\begin{tabular}{|c|c|c|c|c|}
\hline Solution & Insulation system description & $\begin{array}{l}\text { Location of } \\
\text { insulation }\end{array}$ & $\begin{array}{c}\mathrm{Rt} \\
\left(\mathrm{W} / \mathrm{m}^{2 *} \mathrm{~K}\right) \\
\text { of the } \\
\text { system }\end{array}$ & $\begin{array}{l}\text { Unitary Price } \\
\text { Analisys (UF } \\
\qquad / \mathrm{m}^{2} \text { ) }\end{array}$ \\
\hline \multicolumn{5}{|c|}{ For reinforced masonry } \\
\hline Alb.1 & $\begin{array}{l}\text { Poligyp system RH (10mm plaster cardboard } \\
\text { plate with expanded polystyrene }\left(15 \mathrm{~kg} / \mathrm{m}^{3}\right) 10 \\
\mathrm{~mm} \text {, bonded) }\end{array}$ & Inside of the wall & 0.8 & 0.54 \\
\hline Alb.2 & $\begin{array}{l}\text { Andes Termo FFS system with thermal } \\
\text { insulation of expanded polystyrene of } 15 \mathrm{~kg} / \\
\left.\mathrm{m}^{3} \text { (EIFS } 30 \mathrm{~mm}\right)\end{array}$ & $\begin{array}{l}\text { Outside of the } \\
\text { wall }\end{array}$ & 1.2 & 1.21 \\
\hline Alb.3 & $\begin{array}{l}\text { Polyplac system RH (RH plaster cardboard plate } \\
10 \mathrm{~mm} \text { with expanded polystyrene }\left(15 \mathrm{~kg} / \mathrm{m}^{3}\right) \\
10 \mathrm{~mm} \text { bonded) }\end{array}$ & Inside of the wall & 0.766 & 0.54 \\
\hline Alb.4 & $\begin{array}{l}\text { Polyplac system ST (ST plaster cardboard plate } \\
10 \mathrm{~mm} \text { with expanded polystyrene }\left(15 \mathrm{~kg} / \mathrm{m}^{3}\right) \\
10 \mathrm{~mm} \text { bonded) }\end{array}$ & Inside of the wall & 0.76 & 0.57 \\
\hline Alb.5 & Thermal stucco $2 \mathrm{~cm}$ & Inside of the wall & 0.603 & 0.29 \\
\hline Alb.6 & Gypsum plaster $1.5 \mathrm{~cm}$ & Inside of the wall & 0.53 & 0.24 \\
\hline Alb.7 & Normal stucco $2 \mathrm{~cm}+$ gypsum plaster $1.5 \mathrm{~cm}$ & $\begin{array}{l}\text { Stucco outside } \\
\text { and gypsum } \\
\text { plaster indside }\end{array}$ & 0.53 & 0.32 \\
\hline Alb.8 & Thermal stucco $1 \mathrm{~cm}$ & Inside of the wall & 0.53 & 0.25 \\
\hline Alb.9 & Thermal stucco $1 \mathrm{~cm}$ on both side & Both sides & 0.57 & 0.40 \\
\hline Alb.10 & Thermal stucco $1 \mathrm{~cm}$ & $\begin{array}{l}\text { Outside of the } \\
\text { wall }\end{array}$ & 0.53 & 0.26 \\
\hline Alb.11 & $10 \mathrm{~mm}$ plasterboard plate & Inside of the wall & 0.81 & 0.74 \\
\hline \multicolumn{5}{|c|}{ For reinforced concrete } \\
\hline Hor.1 & $\begin{array}{l}\text { Galvanized steel plate coated with cement and } \\
\text { carrying mineral wool }\end{array}$ & Inside of the wall & 1.37 & 0.66 \\
\hline Hor.2 & $\begin{array}{l}\text { EIFS (System formed by a cementitious base in } \\
\text { contact with the concrete that adds expanded } \\
\text { polystyrene. It has a glass net over it that is } \\
\text { covered with an imprimatur and an adherence } \\
\text { bridge so a mortar-type completion can be } \\
\text { applied later) } 20 \mathrm{~mm} \text { (expanded polystyrene de } \\
15 \mathrm{~kg} / \mathrm{m}^{3} \text { ) }\end{array}$ & $\begin{array}{l}\text { Outside of the } \\
\text { wall }\end{array}$ & 0.77 & 1.12 \\
\hline Hor.3 & $\begin{array}{l}\text { EIFS } 20 \mathrm{~mm} \text { (expanded polystyrene de } 20 \\
\mathrm{~kg} / \mathrm{m}^{3} \text { ) }\end{array}$ & $\begin{array}{l}\text { Outside of the } \\
\text { wall }\end{array}$ & 0.85 & 1.54 \\
\hline Hor.4 & Plates thermo aerated concrete veneer & $\begin{array}{l}\text { Outside of the } \\
\text { wall }\end{array}$ & 0.53 & 0.62 \\
\hline Hor.5 & EIFS + Plates thermo aerated concrete veneer & $\begin{array}{l}\text { Outside of the } \\
\text { wall }\end{array}$ & 0.989 & 0.87 \\
\hline
\end{tabular}

Then, the simulations with different thermal insulation solutions for masonry give the following saving percentages (Figure 5).

It is observed that Alb. 2, which possesses an EIFS system of $30 \mathrm{~mm}$, is the solution that gives better results that go from $29 \%$ to $49 \%$ of saving. It is noteworthy that this result was expectable for two reasons: firstly, it is the solution that exhibits the major thermic resistance $\left(1.2 \mathrm{~W} / \mathrm{m}^{2 *} \mathrm{~K}\right)$ which is translated into higher resistance to heat transference. Secondly, it is a solution placed in the outside side of the walls, which allows taking advantage of the Thermal Inertia of the reinforced masonry. 
Figure 5. Saving percentages for the solutions for masonry. Source: Self-authorship.

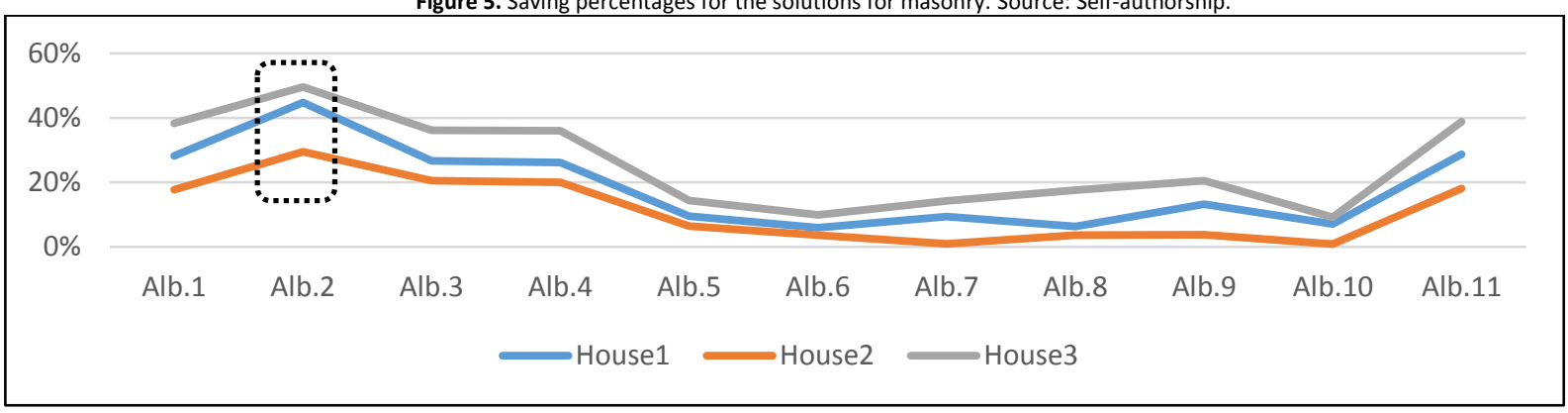

In the same way, different concrete thermic insulation solutions simulations result in the following saving percentages (Figure 6).

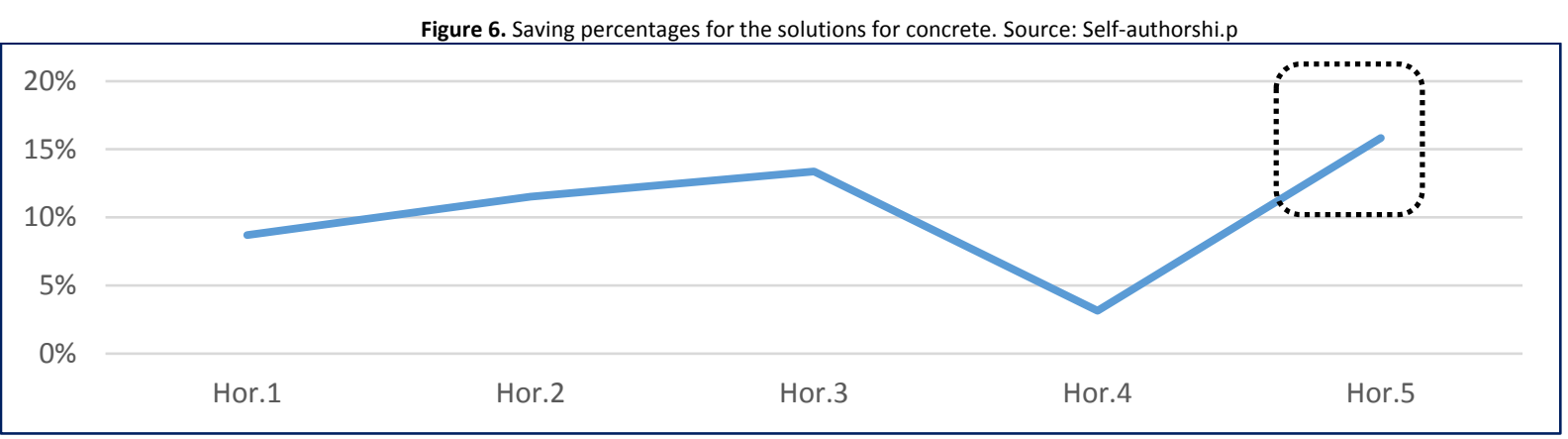

It is observed that the ranging solution by EIFS + cellular concrete plating thermal plaques (Hor. 5) is the one which presents the best performance generating $16 \%$ in saving. In this case, said solution is not the one that displays the highest thermal resistance (Hor. 1 with $1.37 / \mathrm{m}^{2 *} \mathrm{~K}$ ). This can be explained because Hor. 1 is the only solution applied from within the living places and, secondly, Hor. 5 possesses the second highest thermal resistance $\left(0.989 \mathrm{~W} / \mathrm{m}^{2 *} \mathrm{~K}\right)$ and it is applied from outside the house, which allows taking advantage of the concrete thermal inertia.

\section{Economic Analysis}

According to the obtained UPA from Table 2 and the annual heating demands from Table 3 and Figures 2 and 3 , the following comparative tables are acquired between cost to insulate the living places and every thermal solution and saved money in a year (UF) for masonry and concrete. This analysis consider the GLP price is UF/kg 0.038 (CNE, 2015). (Comisión Nacional de Energía, 2015) and a the GLP heat output is $12.052 \mathrm{kCal} / \mathrm{kg}$.

Table 2. Cost for insulate with any solution to any house of masonry. Source: Self-authorship.

\begin{tabular}{lccccccc}
\hline & \multicolumn{3}{c}{ Cost to insulate (UF) } & & \multicolumn{2}{c}{ Money saved per year (UF/year) } \\
\cline { 2 - 4 } Solution & House 1 & House 2 & House 3 & & House 1 & House 2 & House 3 \\
\hline Alb.1 & 34.6 & 36.3 & 91.9 & & 6.7 & 10.5 & 30.4 \\
Alb.2 & 61.5 & 64.3 & 162.9 & & 10.6 & 11.9 & 36.2 \\
Alb.3 & 34.5 & 36.1 & 91.4 & & 6.3 & 10.2 & 31.8 \\
Alb.4 & 36.48 & 38.19 & 96.76 & & 6.2 & 10.2 & 31.6 \\
Alb.5 & 21.6 & 22.7 & 57.5 & & 2.2 & 7.6 & 24.8 \\
Alb.6 & 21.5 & 22.5 & 57.0 & & 1.4 & 7 & 23.4 \\
Alb.7 & 35.2 & 36.9 & 93.5 & & 2.2 & 7.6 & 22.1 \\
Alb8 & 17.4 & 18.3 & 46.2 & & 1.5 & 8 & 23.4 \\
Alb.9 & 26.0 & 27.3 & 68.9 & & 3.1 & 8.3 & 23.5 \\
Alb.10 & 17.3 & 18.2 & 46.1 & & 1.7 & 6.9 & 22 \\
Alb.11 & 27.7 & 29.0 & 73.4 & & 6.8 & 10.6 & 30.6 \\
\hline
\end{tabular}




\begin{tabular}{ccc}
\multicolumn{3}{c}{ Table 5. Cost for insulate with any solution to any house of concrete. Source: Self-authorship. } \\
\hline Solution & $\begin{array}{c}\text { Cost to insulate } \\
\text { House } 4 \text { (UF) }\end{array}$ & $\begin{array}{c}\text { Money saved per year } \\
\text { for house } 4 \text { (UF/year) }\end{array}$ \\
\hline Hor.1 & 25.26 & 17.1 \\
Hor.2 & 42.70 & 17.4 \\
Hor.3 & 58.41 & 17.6 \\
Hor.4 & 6.13 & 16.6 \\
Hor.5 & 33.24 & 17.8 \\
\hline
\end{tabular}

The PPPF establishes that if a living place possessed a Municipal Reception Certificate prior to January $4^{\text {th }}$ of 2007 , it would obtain UF 110. Otherwise, the amount would be UF 55 (Ministerio de Vivienda y Urbanismo, 2006).

The houses 1 and 3 hold a Municipal Reception Certificate prior to January $4^{\text {th }} 2007$. That is why they can apply to a UF 110 subsidy. House 2 can apply to a UF 55 subsidy.

It is understood that the best option for each living place will be the ones that maximize saving and can be funded by the subsidy.

Therefore, the best options for each house are the following:

- $\quad$ Living place 1: Solution Alb. 2

- $\quad$ Living place 2: Solution Alb. 2

- $\quad$ Living place 3: Solution Alb. 4 (in this case, the subsidy does not fund any solution entirely. UF 110 is what it was established for Solution Alb. 2. That is why the one which generated more saving was the selected, without considering Alb. 2)

- $\quad$ Living place 4: Solution Hor. 5

In order to extrapolate this information to RM, as it was already mentioned in previous chapters, the hypothesis will be that there are $1,803,400$ prospect houses to be potential subsidy recipient in RM. These will be represented by the living places $1,2,3$ and 4 with a $27.3 \%, 16.3 \%, 6.0 \%$ and $14.6 \%$ respectively, according to the formerly performed analysis in this research.

The General Preparation Methodology and Project Evaluation (Ministerio de Desarrollo Social, 2013) features the methodology to make decisions of social nature. Within this, it is found that, in order to evaluate a project, it can be used the Cost-Benefit approach. At the same time, within the latter, costs and benefits have to be identified and quantified which would undertake a project to, subsequently, buy them.

The identified benefit is the money saving that it would produce to need less heating to reach a comfort situation. To quantify the money saving would be as it follows:

- $\quad$ Living place 1: UF 10.6 per year

- $\quad$ Living place 2: UF 11.9 per year.

- $\quad$ Living place 3: UF 31.6 per year.

- $\quad$ Living place 4: UF 17.8 per year.

Enlarging these results to RM (Equation 1. Saving money in heating for RM.):

$\left(\frac{10.6 * 27.3 \%+11.9 * 16.3 \%+31.6 * 6 \%+17.8 * 14.6 \%}{0.642}\right) * 1,803,400$

UF 26,203,514 per year.

The identified cost is the thermal insulation solution installation cost.

To quantify the costs would be as it follows:

- $\quad$ Living place 1: UF 61.5

- $\quad$ Living place 2: UF 64.3

- $\quad$ Living place 3: UF 96.76

- $\quad$ Living place 4: UF 33.24 
Enlarging these results to RM (Equation 2. Cost for any solution of insulation):

$\left(\frac{61.5 * 27.3 \%+64.3 * 16.3 \%+96.76 * 6 \%+33.24 * 14.6 \%}{0.642}\right) * 1,803,400$

UF $106,510,322$

Then, a net benefit flux is applied. For that research, 15 years useful life span was considered and a social rate of $10 \%$ discount. Regarding this:

NPV: UF $334,792,796$. IRR: $33 \%$

Net present value (NPV) is the difference between the present value of cash inflows and the present value of cash outflows over a period of time. NPV is used in capital budgeting and investment planning to analyze the profitability of a projected investment or project.

Internal rate of return (IRR) is a metric used in capital budgeting to estimate the profitability of potential investments. Internal rate of return is a discount rate that makes the net present value (NPV) of all cash flows from a particular project equal to zero.

Both concepts (NPV and IRR) are used in Preparation and Project Evaluation General Methodology (Ministerio de Desarrollo Social, 2013)

It is interesting to note that according to (García Pérez de Arce, 2012) the NPV is (adapted) \$7 billion; that is; UF $257,000,000$. It could be explained because another methodology was used by the author. For example, the discount rate was 3.5\% based on HM Treasury (UK) (instead of $10 \%$ used in this research), exist others study typologies (Arce \& Croxford, 2015) (doesn't present apartment dwellings e.g.), and investment costs and construction budget calculation presented are not completely clear.

\section{Conclusions}

The most money saving solution in heating for the masonry is the Alb. 3. Different factors could explain this phenomenon; nevertheless, the highest thermal resistance is the most likely alternative and also the usage of masonry's thermal inertia. In the case of concrete is Hor. 5, which consists of EIFS + cellular concrete plating, probably for its second highest thermal resistance; however, unlike Alb. 3, Hor. 5 allows taking advantage of the concrete thermal inertia.

Regarding the economic analysis, it is concluded that it is relevant considering the year of the living places' Municipal Reception, because this influences the amount of money that can be applied for reconditioning the house. In the case of Living place 3, the insulation solution that presented the best way of heating saving was not entirely funded by the subsidy; nonetheless, this problem was not involved in the year of Municipal Reception. Being prior to 2007, Living place 3 can still apply the maximum amount of subsidy.

On the other hand, the economic analysis performed displays that the PPPF subsidy 2th title application in RM is profitable. When executed the 15 years analysis, with a social rate of discount of $10 \%$ (commonly it is considered only $8 \%$ ) the economic indicators are positive, giving a NPV of UF $121,089,016$ and IRR of $33 \%$.

It is important to say that this research statistically is not completely representative because the sample universe is small. However, authors think that this research can help for another research that consider more study cases.

Finally, the authors consider of vital importance that the analyzed option can be deemed as viable (apply the PPPF, 2th title in RM) given the benefits that this conveys; not just the already exposed economic ones, but the social and environmental. Scilicet, labor and school absenteeism reduction are associated to the comfort conditions, higher labor and school productivity, energy consumption is reduced, greenhouse effect gas emissions are shortened, etc. Also, is important consider other topics for efficiently improve houses in Chile, for example, Muñoz \& Bobadilla (2012) do mention to thermal bridges in construction, using theoretical and experimental methods.

It is essential do a global and holistic assessment of the design, construction and use of the construction industry in Chile. 
Comisión Nacional de Energía. (2015). Precios observados a público: Promedios nominales en regiones y región metropolitana de gas corriente y catalítico en cilíndros. Santiago. Chile. Available online https://www.cne.cl/wpcontent/uploads/2015/05/precios_gas_licuado_en_el_pais7.xlsx

Corporación de Desarrollo Tecnológico (CDT). (2010). Estudio de Usos Finales y Curva de Oferta de Conservación de la Energía en el Sector Residencial de Chile. Santiago. Cámara la Chilena de la http://dataset.cne.cl/Energia_Abierta/Estudios/Minerg/Usos\%20finales\%20y\%20curva\%20de\%20oferta\%20de\%20conservaci\%C3\%B3n\%20de \%20la\%20energ\%C3\%ADa\%20en\%20el\%20sector\%20de\%20residencial\%20de\%20Chile.pdf

División de Prospectiva y Política Energética del Ministerio de Energía. (2012). Balance Nacional de Energía 2011. Santiago. Chile. Available online at: http://datos.energiaabierta.cl/datasets/71049-balance-energetico-2011.download/

García Pérez de Arce, P., \& Croxford, B. (2012). Políticas para reducir el consumo de energía en viviendas de la Región Metropolitana de Chile, por situación socioeconómica y tipo de hogar. Revista Hábitat Sustentable, 2(2), 2-18. Available online at: http://revistas.ubiobio.cl/index.php/RHS/article/view/416

García-Alvarado, R., González, A., Bustamante, W., Bobadilla, A., \& Muñoz, C. (2014). Características relevantes de la simulación energética de viviendas unifamiliares. Informes de la Construcción, 66 (533): e005, doi: http://dx.doi.org/10.3989/ic.12.108

González Cáceres, A., \& Díaz Cisternas, M. (2013). Función e impacto del archivo climático sobre las simulaciones de demanda energética. Revista Hábitat Sustentable. 3(2), 75-85. Available online at: http://revistas.ubiobio.cl/index.php/RHS/article/view/437/399

Instituto Nacional de Estadísticas. (2012). División Político-Administrativa y Censal. Santiago. Chile. Available online at: https://www.cooperativa.cl/noticias/site/artic/20130425/asocfile/20130425190105/resultados_censo_2012_poblacion_vivienda_tomosiyii.p df

Lobos, D., Wandersleben, G., \& Castillo, L. S. (2013). Mapeo de Interoperabilidad entre BIM y software de Simulación Energética para Chile. Congreso de la Sociedad Iberoamericana de Gráfica Digital, (pp. 378-382). Valparaíso. Available online at: http://pdf.blucher.com.br.s3-sa-east1.amazonaws.com/designproceedings/sigradi2013/0072.pdf

Ministerio de Desarrollo Social. (2013). Metodología General de Preparación y Evaluación de Proyectos. Santiago. Chile. Available online at: http://sni.ministeriodesarrollosocial.gob.cl/download/metodologia-general/?wpdmdl=855

Ministerio de Energía. (2014). Agenda de Energía. Santiago. Chile. Available online at: http://www.energia.gob.cl/sites/default/files/agenda_de_energia_-_resumen_en_espanol.pdf

Ministerio de Vivienda y Urbanismo. (2006). Reglamenta Programa de Protección del Patrimonio Familiar. Santiago. Chile. Available online at: http://www.minvu.cl/incjs/download.aspx?glb_cod_nodo=20131008125015\&hdd_nom_archivo=DS255.pdf

Ministerio de Vivienda y Urbanismo. (2014). Listado Oficial de Soluciones Constructivas para Acondicionamiento Térmico del Ministerio de Vivienda y Urbanismo. Santiago. Chile. Available at: http://www.minvu.cl/incjs/download.aspx?glb_cod_nodo=20070606164405\&hdd_nom_archivo=Listado\%20T\%C3\%A9rmico\%2011.pdf

Muñoz, C., \& Bobadilla, A. (2012). Simulación y evaluación de puentes térmicos: Soluciones constructivas típicas aprobadas por la Norma Térmica para elementos verticales en estructura de madera y metálicos en la Zona 4 Simulaciones con Therm y Usai y evaluación con Método de Cámara Térmica. Revista de la Construcción, 11(2), 92-111. https://dx.doi.org/10.4067/S0718-915X2012000200009 